\title{
PERAN REGULASI EMOSI DAN DUKUNGAN SOSIAL PASANGAN TERHADAP KECEMASAN PADA PRIMIGRAVIDA (KEHAMILAN PERTAMA) TRIMESTER KETIGA
}

\author{
Kadek Irayani Pratiwi ${ }^{1}$, Luh Made Karisma Sukmayanti ${ }^{2}$ \\ Email: irayani.pratiwi@gmail.com ${ }^{\underline{1}}$ \\ Universitas Udayana ${ }^{1,2}$
}

\begin{abstract}
Abstrak
Kehamilan merupakan masa pertama dari terbentuknya siklus kehidupan manusia dan merupakan perubahan keadaan yang baru, khususnya bagi perempuan yang pertama kali mengalaminya (primigravida). Pada trimester ketiga, adaptasi psikologis perempuan hamil berkaitan dengan bayangan risiko kehamilan dan proses persalinan, sehingga perempuan hamil dapat menjadi sangat emosional dan cenderung cemas dalam upaya mempersiapkan segala sesuatu yang mungkin akan dihadapinya. Terjadinya kecemasan kehamilan pertama berkaitan dengan regulasi emosi dan dukungan pasangannya.Ketidakmampuan dalam meregulasi emosi selama menjalani masa akhir kehamilan dapat menyebabkan terjadinya kecemasan.Dukungan sosial pasangan yang rendah dapat membuat perempuan hamil pertama merasa kesulitan dalam menjalani masa akhir kehamilannya dikarenakan ketidaktahuannya dalam mengatasi perubahan yang terjadi.Penelitian ini menggunakan metode kuantitatif yang bertujuan untuk mengetahui peran regulasi emosi dan dukungan sosial pasangan terhadap kecemasan pada primigravida (kehamilan pertama) trimester ketiga.Subjek dalam penelitian ini adalah 75 perempuan yang sedang menjalani masa akhir kehamilan pertamanya berusia 20-35 tahun dan tinggal bersama pasangannya.Teknik analisis data yang digunakan dalam penelitian ini adalah regresi berganda. Hasil uji regresi berganda menunjukkan bahwa nilai koefisien regresi sebesar 0,659 dan nilai koefisien determinasi sebesar 0,435 dengan nilai signifikansi sebesar $0,000(\mathrm{p}<0,05)$. Nilai koefisien beta terstandarisasi pada variabel regulasi emosi sebesar -0,199 dan pada variabel dukungan sosial pasangan sebesar -0,546.Hasil dari analisis data tersebut menunjukkan bahwa regulasi emosi dan dukungan sosial pasangan secara bersama-sama berperan terhadap kecemasan kehamilan pertama trimester ketiga.
\end{abstract}

Kata Kunci: Dukungan Sosial Pasangan, Kecemasan Kehamilan Pertama Trimester Ketiga, Regulasi Emosi

\section{PENDAHULUAN}

Kehamilan merupakah sebuah anugrah bagi seorang perempuan berkeluarga yang mengharapkan kehadiran seorang anak.Kehamilan merupakan perubahan yang relatif baru, khususnya untuk perempuan yang baru pertama kali mengalaminya (primigravida).Masa kehamilan berlangsung selama 9 bulan dan terbagi menjadi tiga masa, yaitu masa trimester pertama atau tiga bulan pertama, trimester kedua, dan trimester ketiga.Pada trimester pertama dan kedua, perempuan hamil mengalami gejala seperti mual dan muntah pada pagi hari, berkurangnya nafsu makan, serta kelelahan (Sarasmita, 2018). Pada trimester ketiga, ketika memasuki bulan ke 7 kehamilan, adaptasi psikologis perempuan hamil berkaitan dengan bayangan risiko kehamilan dan proses persalinan, sehingga perempuan hamil sangat emosional dalam upaya mempersiapkan atau mewaspadai segala sesuatu yang mungkin akan dihadapinya (Sutanto \& Fitriana, 2018).

Antara kehamilan pertama dan perempuan yang telah mengalami kehamilan lebih dari satu kali terjadi perbedaan suasana emosional, fisik, 
maupun psikososial. Umumnya reaksi emosional pada kehamilan pertama ditunjukkan dengan adanya rasa kecemasan, ketakutan, dan kepanikan akan kehamilannya terutama menjelang persalinan Hal ini dikarenakan kehamilan pertama belum memiliki pengalaman terkait dengan persalinan dibandingkan dengan perempuan yang telah mengalami kehamilan lebih dari satu kali (Damayanti, Maita, \& Triana, 2014).

Menurut Nurdiana (dalam Sarasmita, 2018), rasa cemas yang dialami oleh perempuan hamil disebabkan karena meningkatnya hormon progesteron.Peningkatan hormon tersebut juga menyebabkan gangguan perasaanmeliputi mudah marah, cemburu, keinginan untuk selalu diperhatikan, depresi, perasaan tidak nyaman, dan mengalami kecemasan (Pieter \& Lubis, 2010). Kecemasan perempuan hamil akan meningkat ketika usia kehamilan memasuki trimester ketiga terutama ketika memasuki bulan ketujuh kehamilan. Peningkatan rasa cemas ini berkaitan dengan dekatnya masa kelahiran bayi (Sarasmita, 2018). Meskipun peristiwa kelahiran merupakan sesuatu yang normal, namun keyataannya persalinan merupakan suatu hal yang tidak pasti dan membawa risiko kematian, bahkan beberapa proses persalinan disertai dengan adanya pendarahan rasa sakit yang luar biasa sehingga beberapa peristiwa ini menimbulkan ketakutan dan berujung kecemasan pada perempuan hamil (Pieter \& Lubis, 2010). Penelitian serupa yang sejalan dengan penelitian ini dilakukan oleh Arafah dan Aizar (2011) yangmenunjukkan bahwa kecemasan pada perempuan dengan kehamilan pertama dialami karena persepsi yang kurang tepat mengenai proses persalinan. Hal ini membuat perempuan hamil merasakan kecemasan dalam menjalani masa akhir kehamilannya.

Dampak buruk yang terjadi pada perempuan hamil trimester ketiga akibat mengalami kecemasan yaitu komplikasi pada kehamilan berupa tekanan darah tinggi yang terjadi di dalam kehamilan akhir atau pada proses persalinan (preeclampsia) dan kelahiran bayi yang kurang dari usia kehamilan 37 minggu atau bayi lahir dengan berat kurang dari 2500 gram (premature) (Maharani, 2008). Hal tersebut dapat meningkatkan angka kematian ibu dan bayi dengan berat badan lahir rendah (BBLR). Perempuan hamil diharapkan dapat menghadapi kecemasan selama kehamilan dengan baik sehingga calon bayi dan perempuan hamil terhindar dari dampak buruk kecemasan seperti preeclampsia, maka dari itu diperlukannya regulasi emosi selama masa 
kehamilan khususnya menjelang trimester ketiga. Regulasi emosi merupakan kemampuan yang dimiliki oleh individu untuk mengelola, menilai, mengatasi, dan mengungkapkan emosi yang tepat untuk mencapai keseimbangan emosional (Gross, 2014). Penelitian yang dilakukan oleh Hendriati (2018) menunjukkan bahwa sebagian besar perempuan hamil belum memahami bagaimana cara memvalidasi emosi dan mengelola emosinya, sehingga regulasi emosi yang baik sangat diperlukan untuk mengurangi kecemasan pada kehamilan. Emosi negatif yang berlangsung lama dan tidak ditangani akan menimbulkan dampak negatif bagi perempuan hamil dan calon bayi.

Selain memiliki kemampuan regulasi emosi yang baik, terdapat faktor lain untuk mengatasi kecemasan pada perempuan hamil yaitu dukungan sosial. Dukungan sosial dapat diperoleh dari keluarga, pasangan, kerabat, teman, komunitas (Taylor, 2015).Dukungan sosial yang paling dekat dengan perempuan hamil adalah dukungan dari pasangannya (Pieter \& Lubis, 2010).Seorang perempuan sejak hamil sampai dengan persalinan sebaiknya mendapatkan pendampingan secara psikologis agar mampu menjalani kehamilan, persalinan dan pasca persalinan dengan nyaman. Adanya dukungan pasangan yang diberikan terhadap istri saat menghadapi persalinan diasumsikan akan memberi kontribusi yang baik, seperti rasa tenang dan nyaman sehingga dapat mengurangi tingkat kecemasan menjelang persalinan. Bentuk dukungan pasangan dapat berupa pujian, memberikan semangat dan nasehat yang dapat membuat penerima dukungan akan merasa disayang dan dihargai (Setiadi, 2008). Menurut hasil penelitian yang dilakukan oleh Geme (2018), sebanyak $52,2 \%$ perempuan hamil mendapat dukungan dari pasangannya dengan kategori tinggi, sehingga hal ini dapat mengurangi kecemasan menjelang persalinan.

Berdasarkan penjelasan yang telah dipaparkan,peneliti merasa perlu untuk menyelisik peranan dari regulasi emosi dan dukungan sosial pasangan pada kehamilan pertama trimester ketiga sebagai upaya untuk menghadapi kecemasan pada kehamilan.

\section{KAJIAN PUSTAKA}

\section{Kecemasan Kehamilan Pertama}

\section{Trimester Ketiga.}

Menurut Sarasmita (2018), pada trimester ketiga kecemasan dan ketidaknyamanan dari perempuan hamil semakin meningkat. Peningkatan rasa cemas pada trimester ketiga ini terutama 
memasuki bulan ke delapan kehamilan berkaitan dengan dekatnya masa kelahiran bayi.Nevid, Rathus, dan Greene (2014) menjelaskan bahwa kecemasan merupakan suatu keadaan emosional yang mempunyai ciri keterangsangan fisiologis, perasaan tegang yang tidak menyenangkan, dan kekhawatiran bahwa sesuatu yang buruk akan terjadi. AspekAspek kecemasan menurut Nevid, Rathus, dan Greene (2014) yakni: Fisik yang meliputi kegelisahan, gugup, tangan atau tubuh yang bergetar, mengeluarkan keringat berlebih, nafas pendek, jantung yang berdetak kencang; Perilaku meliputi perilaku menghindar, tergantung; Kognitif meliputi ketakutan akan sesuatu hal yang terjadi di masa depan, berfikir tentang hal yang mengganggu secara berulang.

\section{Regulasi Emosi}

Gross (2014) menjelaskan bahwa regulasi emosi adalah kemampuan yang dimiliki oleh seseorang untuk menilai, mengatasi,mengelola dan mengungkapkan emosi yang tepat untuk mencapai keseimbangan emosional.Gross (2014)Mengatakan bahwa terdapat empat aspek dalam regulasi emosi yaitu strategi regulasi emosi yakni kemampuan seseorang dalam menemukan cara yang tepat dalam menghadapi emosi; perilaku yang mengarah pada suatu tujuan, merupakan kemampuan individu untuk tidak terpengaruh emosi negatif yang dirasakanya; kontrol respon emosional, merupakan kemampuan individu untuk dapat mengontrol emosi yang dirasakannya; dan penerimaan respon emosional merupakan kemampuan individu untuk menerima suatu peristiwa yang menimbulkan emosi negatif.

\section{Dukungan Sosial Pasangan}

$$
\text { Menurut Sarafino }
$$
dukungan sosial merupakan dukungan yang diberikan kepada individu khususnya ketika dibutuhkan oleh orang-orang yang memiliki hubungan emosional yang dekat dengan orang tersebut di lingkungan sosialnya. Dukungan selama masa kehamilan sangat dibutuhkan bagi seorang perempuan hamil, terutama bagi perempuan yang mengalami kehamilan pertamanya.Dukungan sosial yang paling dekat dengan perempuan hamil adalah dukungan yang berasal dari pasangannya.Terdapat 4 aspek dalam dukungan sosial, meliputi : dukungan informasional berupa pemberian saran atau informasi, dukungan instrumental berupa pemberian dukungan melalui materi, dukungan pendampingan meliputi kehadiran orang lain yang memiliki hubungan emosional dengan individu, dukungan emosional meliputi empati dan kasih sayang. 


\section{METODE PENELITIAN}

Populasi penelitian ini adalah seluruh perempuan yang mengalami kehamilan untuk pertama kalinya dengan usia kehamilan berada pada trimester ketiga. yang berkunjung ke tempat praktekTeknik pengambilan sampel pada penelitian ini adalah purposive sampling, yaitu penentuan anggota sampel dengan didasarkan atas ciri-ciri atau karakteristik tertentu. Sampel dalam penelitian ini mempunyai karateristik tertentu yakni: perempuan yang sedang mengalami kehamilan pertama memiliki suami dan tinggal bersama suami; usia kehamilan berada pada trimester ketiga; usia perempuan yang sedang menjalani kehamilannya berada pada rentang 20 sampai 35 tahun.

Penelitian dilaksanakan pada bulan Mei 2020.Penelitian dilakukan di beberapa tempat praktek/klinik dokter kandungan di Denpasar dengan menggunakan skala dalam bentuk google form. Jumlah total subjek yakni 150 orang, kemudian peneliti mengundi responden tersebut sehingga jumlah yang mengikuti penelitian ini sebanhyak 75 orang.

\section{Alat Ukur}

Alat ukur penelitian ini menggunakan skala Likertdengan ketiga skala dari variabel penelitian meliputi Skala
Kecemasan Kehamilan Pertama Trimester Ketiga yang berjumlah 29 aitem, Skala Regulasi Emosi yang berjumlah 32 aitem, Skala Dukungan Sosial Pasangan yang berjumlah 27 aitem. Uji validitas alat ukur dilaksanakan pada bulan April 2020 dengan subjek perempuan hamil pertama trimester ketiga sebanyak 67 orang.Proses uji coba dilakukan dengan menyebar skala dalam bentuk google form. Aitem-aitem pada Skala Kecemasan Kehamilan Pertama Trimester Ketiga memiliki koefisien korelasi aitem-total berkisar 0,308 sampai 0,806.Aitem-aitem pada Skala Regulasi emosi memiliki koefisien korelasi aitem-total berkisar 0,357 sampai 0,752.Aitem-aitem pada Skala Dukungan Sosial Pasangan memiliki koefisien korelasi aitem-total berkisar 0,364 sampai 0,845 .

\section{HASIL DAN PEMBAHASAN}

Berdasarkan hasil perhitungan batas atas (skor minimum) dan batas atas (skor maksimum), hasil tersebut dimasukan kedalam kategorisasi tiap variabel yang dilihat dalam 4 kategori, yaitu sangat tinggi, tinggi, rendah, dan sangat rendah.

Tabel 1.Kategorisasi Kecemasan Kehamilan Pertama Trimester Ketiga.

\begin{tabular}{|c|c|c|c|}
\hline $\begin{array}{c}\text { Rentang } \\
\text { Nilai }\end{array}$ & Kategori & Jumlah & Persentase \\
\hline $\mathrm{X} \leq 50,75$ & $\begin{array}{c}\text { Sangat } \\
\text { Rendah }\end{array}$ & 11 & $14,7 \%$ \\
\hline $\begin{array}{c}50,75<\mathrm{X} \\
\leq 65,25\end{array}$ & Rendah & 60 & $80,0 \%$ \\
\hline
\end{tabular}




\begin{tabular}{|c|c|c|c|}
\hline $\begin{array}{c}65,25<\mathrm{X} \\
\leq 79,75\end{array}$ & Sedang & 3 & $4,0 \%$ \\
\hline $\begin{array}{c}79,75<\mathrm{X} \\
\leq 94,25\end{array}$ & Tinggi & 1 & $1,3 \%$ \\
\hline $94,25<\mathrm{X}$ & $\begin{array}{c}\text { Sangat } \\
\text { Tinggi }\end{array}$ & 0 & $0 \%$ \\
\hline & Total & 75 & $100 \%$ \\
\hline
\end{tabular}

Berdasarkan hasil kategorisasi dari

variabel kecemasan kehamilan pertama trimester ketiga bahwa dapat dijelaskan bahwa subjek dalam penelitian ini memiliki taraf kecemasan kehamilan pertama yang cenderung rendah.

Tabel 2. Kategorisasi Regulasi Emosi.

\begin{tabular}{cccc}
\hline $\begin{array}{c}\text { Rentang } \\
\text { Nilai }\end{array}$ & Kategori & Jumlah & Persentase \\
\hline $\mathrm{X} \leq 45,5$ & $\begin{array}{c}\text { Sangat } \\
\text { Rendah }\end{array}$ & 0 & $0 \%$ \\
\hline $\begin{array}{c}45,5<\mathrm{X} \\
\leq 58,5\end{array}$ & Rendah & 0 & $0 \%$ \\
\hline $\begin{array}{c}58,5<\mathrm{X} \\
\leq 71,5\end{array}$ & Sedang & 14 & $18,7 \%$ \\
\hline $\begin{array}{c}71,5<\mathrm{X} \\
\leq 84,5\end{array}$ & Tinggi & 43 & $57,3 \%$ \\
\hline $\begin{array}{c}84,5<\mathrm{X} \\
\text { Sangat }\end{array}$ & $\begin{array}{c}\text { Tinggi } \\
\text { Total }\end{array}$ & 75 & $24,0 \%$ \\
\hline Berdasarkan & hasil & kategorisasi
\end{tabular}

pada tabel 2, maka dapat dijelaskan bahwa subjek dalam penelitian ini memiliki taraf regulasi emosi yang cenderung tinggi.

Tabel 3. Kategorisasi Dukungan Sosial Pasangan.

\begin{tabular}{cccc}
\hline $\begin{array}{c}\text { Rentang } \\
\text { Nilai }\end{array}$ & Kategori & Jumlah & Persentase \\
\hline $\mathrm{X} \leq 47,25$ & $\begin{array}{c}\text { Sangat } \\
\text { Rendah }\end{array}$ & 0 & $0 \%$ \\
\hline $\begin{array}{c}47,25<\mathrm{X} \\
\leq 60,75\end{array}$ & Rendah & 0 & $0 \%$ \\
\hline $\begin{array}{c}60,75<\mathrm{X} \\
\leq 74,75\end{array}$ & Sedang & 4 & $5,3 \%$ \\
\hline $\begin{array}{c}74,75<\mathrm{X} \\
\leq 87,75\end{array}$ & Tinggi & 22 & $29,3 \%$ \\
\hline $\begin{array}{c}87,75<\mathrm{X} \\
\mathrm{C}\end{array}$ & $\begin{array}{c}\text { Sangat } \\
\text { Tinggi }\end{array}$ & 49 & $65,3 \%$ \\
\hline Total & 75 & $100 \%$ \\
\hline
\end{tabular}

Berdasarkan hasil kategorisasi pada tabel 3, maka dapat dijelaskan bahwa subjek dalam penelitian ini memiliki taraf dukungan sosial pasangan yang cenderung tinggi.

\section{Uji Asumsi Penelitian}

Penelitian ini menggunakan teknik analisis data regresi berganda. Sebelum melakukan uji analisis regresi berganda, data-data dalam penelitian ini harus memenuhi uji asumsi penelitian, yaitu uji normalitas, uji linearitas, dan uji multikolonieritas

\section{Uji Normalitas}

Uji normalitas digunakan untuk menguji normal tau tidaknya sebaran data dari ketiga variabel. Data dikatakan normal apabila nilai Kolmogorov-Smirnov lebih besar dari 0,05 ( $p>0,05)$.

Tabel 4. Hasil Uji Normalitas

\begin{tabular}{cccc}
\hline Variabel & $\begin{array}{c}\text { Kolmogoro } \\
\text { v-Smirnov }\end{array}$ & Sig. & $\begin{array}{c}\text { Kesimp } \\
\text { ulan }\end{array}$ \\
\hline $\begin{array}{c}\text { Kecemas } \\
\text { an }\end{array}$ & 0,878 & 0,424 & $\begin{array}{c}\text { Data } \\
\text { Normal }\end{array}$ \\
$\begin{array}{c}\text { kehamila } \\
\text { n pertama } \\
\text { trimester } \\
\text { ketiga }\end{array}$ & & & \\
\hline $\begin{array}{c}\text { Regulasi } \\
\text { Emosi }\end{array}$ & 0,806 & 0,535 & $\begin{array}{c}\text { Data } \\
\text { Normal }\end{array}$ \\
\hline $\begin{array}{c}\text { Dukunga } \\
\text { n Sosial }\end{array}$ & 0,478 & 0,976 & $\begin{array}{c}\text { Data } \\
\text { Normal }\end{array}$ \\
Pasangan & & & \\
\hline
\end{tabular}

\section{Uji Linieritas}

Uji linearitas adalah uji yang dilakukan untuk mengetahui hubungan antar variabel yang akan dianalisis apakah memiliki hubungan yang linier atau tidak. 
Hubungan data dari dua variabel dikatakan linier apabila memiliki nilai signifikansi linearity lebih kecil dari 0,05 $(\mathrm{p}<0,05)$. Berdasarkan hasil uji linearitas pada tabel 5, maka dapat dikatakan bahwa terdapat hubungan yang linear antara variabel kecemasan kehamilan pertama trimester ketiga.nilai signifikansi linearity sebesar $0,000(p<0,05)$.

Tabel 5. Hasil Uji Linieritas.

\begin{tabular}{|c|c|c|}
\hline Variabel & Linearity & $\begin{array}{c}\text { Kesimp } \\
\text { ulan }\end{array}$ \\
\hline $\begin{array}{c}\text { Kecemasan } \\
\text { Kehamilan } \\
\text { Trimester } \\
\text { Ketiga*Regulasi } \\
\text { Emosi }\end{array}$ & 0,00 & $\begin{array}{c}\text { Data } \\
\text { Linear }\end{array}$ \\
\hline $\begin{array}{c}\text { Kecemasan } \\
\text { Kehamilan } \\
\text { Trimester } \\
\text { Ketiga*Dukungan } \\
\text { Sosial Pasangan }\end{array}$ & 0,00 & $\begin{array}{c}\text { Data } \\
\text { Linear }\end{array}$ \\
\hline
\end{tabular}

\section{Uji Multikolinieritas}

Uji Multikolinieritas merupakan uji yang dilakukan untuk menguji terkait adanya korelasi atau hubungan antar variabel bebas.Model regresi dapat dikatakan baik apabila tidak terdapat korelasi antar variabel bebas dalam penelitian.Multikolinieritas dapat dilihat dari nilai tolerance dan VIF (Variance Inflation Factor). Dua variabel bebas dikatakan tidak terjadi korelasi apabila memiliki nilai tolerance $\geq 0,1$ dan nilai $V I F \leq 10$. Berdasarkan hasil uji multikolonieritas pada tabel 6 terlihat bahwa tidak terjadiemosi memiliki nilai tolerance tolerance $\geq 0,1$ dan nilai $V I F \leq$
10 sehingga dapat dikatakan bahwa tidak terjadi multikolinieritas antar variabel bebas dalam penelitian ini.

Tabel 6. Hasil Uji Multikolinieritas

\begin{tabular}{cccc}
\hline $\begin{array}{c}\text { Variab } \\
\text { el }\end{array}$ & Tolerance & VIF & $\begin{array}{c}\text { Kesimpula } \\
\mathbf{n}\end{array}$ \\
\hline $\begin{array}{c}\text { Regula } \\
\text { si }\end{array}$ & 0,588 & 1,248 & $\begin{array}{c}\text { Tidak } \\
\text { terjadi } \\
\text { Emosi }\end{array}$ \\
& & & $\begin{array}{c}\text { multikolinie } \\
\text { ritas }\end{array}$ \\
\hline $\begin{array}{c}\text { Dukun } \\
\text { gan }\end{array}$ & 0,588 & 1,248 & Tidak \\
Sosial & & & terjadi \\
Pasang & & & multikolinie \\
an & & & ritas \\
\hline
\end{tabular}

\section{Uji Hipotesis}

Uji hipotesis yang digunakan dalam penelitian ini adalah uji regresi ganda. Menurut Yudiaatmaja (2013), uji regresi ganda digunakan untuk mengetahui peran dari dua variabel bebas atau lebih terhadap satu variabel tergantung. Apabila nilai signifikansi lebih kecil dari $0,05(\mathrm{p}<0,05)$ maka variabel bebas berperan secara signifikan terhadap variabel terikat(Sugiyono, 2018).Hasil uji regresi berganda menunjukkan bahwa nilai $\mathrm{F}$ hitung sebesar 27,702 dengan signifikansi sebesar 0,000 $(\mathrm{p}<0,05)$. Hal ini dapat dikatakan bahwa regulasi emosi dan dukungan sosial pasangan secara bersamasama berperan terhadap kecemasan kehamilan pertama trimester ketiga dengan nilai $\mathrm{R}$ sebesar 0,659 dengan nilai koefisien determinasi ( $R$ Square) sebesar 0,435. Hal tersebut menunjukkan bahwa regulasi emosi dan dukungan sosial 
pasangan memiliki peran sebesar 43,5\% terhadap kecemasan kehamilan pertama trimester ketiga dan variabel yang tidak diteliti memiliki peran sebesar 56,5\% terhadap kecemasan kehamilan pertama trimester ketiga.

\section{PEMBAHASAN}

Berdasarkan analisis uji regresi berganda yang telah dilakukan sebelumnya, variabel regulasi emosi dan dukungan sosial pasangan memiliki peran yang cukup signifikan terhadap variabel kecemasan pada kehamilan pertama trimester ketiga.Variabel regulasi emosi memiliki nilai koefisien beta terstandarisasi sebesar $-0,199$ dan memiliki taraf signifikansi sebesar 0,048 $(\mathrm{p}<0,05)$. Dengan nilai koefisien beta terstandarisasi sebesar -0,199 maka dapat dikatakan bahwa variabel regulasi emosi memiliki hubungan yang negatif.Makna dari nilai negatif pada variabel regulasi emosi terhadap kecemasan kehamilan pertama trimester ketiga adalah apabila semakin tinggi regulasi emosi yang dimiliki oleh perempuan hamil pertama trimester ketiga maka semakin rendah taraf kecemasan yang dimiliki.Beberapa dampak psikologis yang muncul selama menjalani masa akhir kehamilan menuntut perempuan hamil untuk mampu mengelola emosinya.Jika kemampuan yang dimiliki oleh perempuan hamil dalam meregulasi emosi baik, maka emosi-emosi negatif akan lebih mudah untuk diadaptasi menjadi emosi positif. Kemampuan regulasi emosi yang dimiliki oleh setiap orang terutama perempuan yang sedang menjalani trimester akhir kehamilan pertamanya sangat membantu dalam mengendalikan emosi yang terjadi. Kecemasan merupakan bentuk perwujudan dari emosi takut yang ditandai dengan perasaaan akan hadirnya suatu hal yang tidak menyenangkan. Individu yang memiliki taraf regulasi emosi yang tinggiakan mampu untuk mengelola emosi yang dirasakannya termasuk kecemasan.

Berdasarkan hasil uji regresi berganda yang dilakukan pada penelitian ini, nilai koefisien beta terstandarisasi dari dukungan sosial pasangan sebesar -0,546 $(\mathrm{p}<0,05)$. Hal ini menunjukkan bahwa koefisien beta terstandarisasi dari dukungan sosial pasangan lebih besar dibandingkan dengan nilai koefisien beta terstandarisasi dari regulasi emosi, sehingga dapat dikatakan bahwa dukungan sosial pasangan memiliki peran yang lebih besar terhadap kecemasan dibandingan dengan regulasi emosi.Dukungan sosial pasangan memiliki peran yang signifikan terhadap kecemasan kehamilan pertama trimester ketiga yang berarti semakin tinggi taraf dukungan sosial pasangan maka semakin 
rendah kecemasan yang dialami.Perhatian dan dukungan dari orang- orang terdekat terutama suami sangat membantu dalam mengatasi kecemasan yang dialami ibu hamil dalam menjalani masa akhir kehamilan pertamanya. Dukungan suami akan meningkatkan kesejahteraan psikologis dan kemampuan penyesuaian diri melalui perasaan memiliki, peningkatan percaya diri, pencegahan psikologi, pengurangan stress serta penyediaan sumber atau bantuan yang dibutuhkan selama kehamilan (Stuart, 2008).Kehadiran suami memiliki peran penting terhadap perempuan hamil dalam menjalani masa akhir kehamilan pertamanya.Terlebih lagi kehamilan yang dialaminya merupakan pengalaman pertama kali dan ketidaktahuan dapat menjadi salah satu faktor terjadinya kecemasan, sehingga trimester ketiga dirasakan semakin mencemaskan karena semakin dekat dengan proses persalinan (Pieter dan Lubis, 2010). Perempuan hamil yang mendapat dukungan sosial yang cenderung tinggi dari pasangannya, cenderung akan mengubah respon terhadap sumber kecemasan dengan mencurahkan isi hatinya kepada pasangannya. Dukungan dari pasangan dalam masa kehamilan terutama menjelang persalinan dikatakan dapat meningkatkan kesiapan perempuan hamil dalam menghadapi proses persalinan.

\section{PENUTUP \\ Kesimpulan}

Berdasarkan hasil penelitian yang telah dilakukan, maka didapatkan kesimpulan, terdapat peran negatif yang signifikan antara regulasi emosi dan dukungan sosial pasangan terhadap kecemasan kehamilan pertama trimester ketiga.Sebagian besar subjek memiliki taraf regulasi emosi dan dukungan sosial pasangan yang cenderung tinggi dan memiliki taraf kecemasan yang cenderung rendah. Regulasi emosi dan dukungan sosial pasangan secara bersama-sama berperan terhadap kecemasan pada perempuan dengan kehamilan pertama trimester ketiga sebesar $43,5 \%$ sementara $56,5 \%$ lainnya dipengaruhi oleh faktor lain yang tidak diteliti dalam penelitian ini.

\section{Saran}

Berdasarkan hasil penelitian, Berdasarkan kesimpulan diatas, maka saran yang dapat diberikan kepada pihakpihak terkait yakni: Bagi subjek. Bagi perempuan hamil pertama trimester ketiga diharapkan untuk dapat meningkatkankemampuan regulasi emosi serta menyadari pentingnya dukungan sosial dari pasangan. Bagi pasangan. Bagi suami diharapkan untuk memberikan 
dukungan terhadap pasangannya yang sedang menjalani masa kehamilan sehingga dapat memberi bantuan akibat perubahan-perubahan fisik, psikologis selama masa akhir kehamilan. Bagi peneliti selanjutnya.Peneliti selanjutnya dapat melakukan pengambilan data secara langsung dan menggunakan kuesioner dalam bentuk fisik jika penelitian dilakukan tidak dalam kondisi pandemi, sehingga pelaksanaan pengambilan data dapat dikontrol dengan optimal.

\section{DAFTAR PUSTAKA}

Azwar, S.2016.Metode Penelitian. Yogyakarta : Pustaka Pelajar.

Bobak.2010. Buku Ajar Keperawatan Maternitas (Edisi 4). Jakarta: EGC

Cisler, J. M., Olatunji, B. O., Feldner, M. T., \& Forsyth, J. P. 2010. Emotion regulation and the anxiety disorders: An integrative review. Journal of psychopathology and behavioral assessment, 32(1), 68-82

Dale, S.D.,\& Dale. A. E.2019. Psikologi Kebidanan: Memahami Psikis Wanita Sepanjang Daur Hidup dalam Pelayanan Kebidanan. Yogyakarta: Pustaka Baru Press

Damayanti, P., Maita, L., Triana, A. 2014. Buku Ajar: Asuhan Kebidanan Komprahensif Pada Ibu Bersalin Dan Bayi Baru Lahir (Edisi 1). Yogyakarta : Deepublish

Gross, J. 2014. Handbook Of Emotion Regulation( $2^{\text {nd }}$ Ed.). New York : The Guildford Press.
Maharani, T. 2008.Hubungan Antara Dukungan Sosial Dan Kecemasan Dalam Menghadapi Persalinan Pada Ibu Hamil Trimester Ketiga.Skripsi. Fakultas Psikologi Universitas Gunadharma. Jakarta

Sutanto, A., \&Fitriana, Y. 2018. Asuhan Pada Kehamilan (Edisi 1). Yogyakarta : Pustaka Baru Press.

Sarasmita, A. 2018. Farmakologi Obat :

Pada Kehamilan Dan Menyusui :

Edisi pertama. Denpasar :

Udayana University Press

Pieter, Z.,\& Lubis, L. 2010.Pengantar Psikologi Untuk Kebidanan :Edisi Pertama. Jakarta : Penerbit Kencana.

Sarafino, E., P., \& Smith, T. W. 2011.Health Psychology:

Biopsychosocial Interactions $: 7^{\text {th }}$ Edition. USA : John Wiley \& Sons, INC

Sati. 2018. Buku Pintar Kehamilan : Edisi Pertama. Yogyakarta : Brilliant Books.

Sugiyono.2018. Metode Penelitian Kuantitatif, Kualitatif, Dan R\&D (Edisi 28).Bandung : Alfabeta

Sugiyono. 2017. Metode Penelitian Kuantitatif, Kualitatif Dan $R \& D$. Bandung : Alfabeta

Sutanto, A., \&Fitriana, Y. 2018. Asuhan Pada Kehamilan (Edisi 1). Yogyakarta : Pustaka Baru Press.

Taylor, S. E. 2015. Health Psychology (9 $9^{\text {th }}$ Ed.). New York : Mc Graw-Hill Education

Pieter, Z.,\& Lubis, L. 2010.Pengantar Psikologi Untuk Kebidanan :Edisi 
Pertama. Jakarta : Penerbit Kencana.

Nevid, J.S.S., A. Rathus., \&Greene, B. 2005.Psikologi
Abnormal
Terjemahan Tim Psikologi

Universitas Indonesia : Edisi

Kelima. Jakarta: Penerbit Erlangga 